\title{
Rodzaje powiązań integracyjnych w agrobiznesie
}

\section{Wstęp}

Idea wspólnego działania odgrywa we współczesnym świecie coraz ważniejszą rolę. W tym celu łączą się i integrują całe kontynenty, aby osiągnąć korzyści ze wspólnego handlu, a ostatnio także ze wspólnego gospodarowania. Wreszcie łączą się i integrują ze sobą firmy, aby w wyniku wspólnej działalności - często wykraczającej poza granice własnego kraju - zapewnić sobie korzyści większe od tych, które można by osiagnnać w pojedynkę [Małysz 2000]. $\mathrm{Na}$ procesy integracyjne rolnictwa $z$ przetwórstwem $\mathrm{w}$ skali branż $\mathrm{w}$ danym kraju lub regionie wpływaja procesy więziotwórcze w skali międzynarodowej [Piwowar 1998].

W Encyklopedii biznesu ${ }^{1}$ zdefiniowano integracje ekonomiczną jako proces scalania gospodarek, wynikający z dążenia podmiotów je tworzących do poprawy efektywności działania. Proces ten przejawia się w rozbudowie trwałych krajowych oraz międzynarodowych powiązań ekonomicznych, zarówno na szczeblu przedsiębiorstw, branż i regionów, jak też całych gospodarek narodowych.

Wyróżniamy dwie zasadnicze formy integracji²: pionową (wertykalna) i poziomą (horyzontalna); niekiedy mówi się o integracji diagonalnej, czyli na krzyż. Inny podział to integracja pełna i pośrednia. Integracja gospodarcza pełna ma miejsce wówczas, gdy występuje łączenie (fuzja) dwóch lub kilku przedsiębiorstw realizujących określony rodzaj lub kolejne etapy działalności gospodarczej i prowadzi do wytworzenia jednego dużego podmiotu rynkowego. Integracja gospodarcza pośrednia rozwijana jest przez powiązania umowne, $\mathrm{w}$ ramach których poszczególni partnerzy zachowują swoją samodzielność formalno-prawną i w ograniczonym zakresie ekonomiczną.

\footnotetext{
${ }^{1}$ Encyklopedia biznesu, Fundacja Innowacyjna. Warszawa 1995, s. 226.

${ }^{2}$ Integracja jest pojęciem ekonomicznym, oznaczającym procesy gospodarcze polegające na łączeniu działalności różnych podmiotów ekonomicznych. Połączenie działań polega na podporządkowaniu pod jednym zarządem całości lub części decyzji ekonomicznych, rozproszonych dotychczas pomiędzy różne podmioty gospodarcze. Praktycznie integracja następuje wtedy, gdy wszyscy jej uczestnicy korzystają z tej współzależności i odnoszą ekonomiczne korzyści.
} 


\section{Integracja a kooperacja}

Pojęcie integracji jest stosowane do zaawansowanych więzi instytucjonalnych i rzeczowych, natomiast ich początkowe stadia są traktowane jako współpraca i kooperacja. Istnienie różnych wariantów integracji zazębia się z pojęciem kooperacji. W szczególności dotyczy to różnych stopni kooperacji i integracji oraz wzajemnego ich powiązania. Określenia te mogą przybierać znaczenie identyczne lub zbliżone, a nawet przeciwstawne. Między kooperacją a integracją zachodzą jednak istotne różnice. Kooperacja oznacza przede wszystkim szeroko rozumianą współpracę, a jej zasięg obejmuje głównie kategorie ilościowe, natomiast integracja oznacza zmianę jakościowej formy gospodarowania [Zalewski 1989].

Integracja różni się zasadniczo od kooperacji, gdyż jest procesem organizacyjno-gospodarczym prowadzącym do scalania podmiotów z kierownictwem zarządzania. Kooperacja natomiast jednoczy samodzielne podmioty gospodarcze, z których każdy reprezentuje własne interesy. Główna różnica między kooperacja a integracja polega na samodzielności gospodarujących partnerów. Integracja pozioma polega na stopniowym łączeniu współzależnych jednostek gospodarczych i zacieśnianiu więzi między nimi, pionowa zaś jest to łączenie samodzielnych podmiotów [Zalewski 1989].

Głównymi zadaniami integracji przemysłu spożywczego, rolnictwa i obrotu są przede wszystkim [Laskowska, Pieniążek, Zdyb 1987]:

a) zwiększenie efektywności produkcji i sprzedaży, m.in. przez dostosowanie podaży (ilości, jakości i miejsca) do wymagań odbiorców,

b) zmniejszenie ryzyka przez gwarancję:

- dostaw czynników produkcji brakujących uczestnikom zintegrowanego procesu wytwarzania żywności,

- zbytu surowców oraz finalnych produktów żywnościowych,

c) poprawa pozycji rynkowej poszczególnych uczestników.

\section{Rys historyczny procesu integracji}

W procesie integracji przemysłu spożywczego $\mathrm{z}$ otoczeniem rynkowym w Polsce można wyróżnić dwa etapy. W pierwszym, który miał miejsce na początku lat 90 ., nastapił prawie całkowity rozpad dotychczasowych struktur funkcjonalnych w tym przemyśle oraz jego otoczeniu rynkowym. Był to okres rozproszenia zarówno wśród dostawców surowców, jak i odbiorców wyrobów przemysłu spożywczego. 
Tendencje te zmieniły swój kierunek w połowie lat 90 . i ten okres można uznać za początek integracji przemysłu spożywczego z jego otoczeniem rynkowym (początek procesu integracji łańcucha żywnościowego). Świadczyć mogą o tym zmiany w podejściu przedsiębiorstw przemysłu spożywczego do problematyki jakości. Dostrzegły one bowiem konieczność zapewnienia wysokiej jakości surowców do produkcji, dostarczanych w optymalnych ilościach, we właściwym czasie i po optymalnych cenach. Dlatego też wprowadziły wiele zmian w funkcjonowaniu zakładowych służb surowcowych. Na rynku pojawiły się nowe, dotychczas nieistniejące kanały zaopatrzenia surowcowego, takie jak: giełdy towarowe, wielkoobszarowe $\mathrm{i}$ towarowe prywatne gospodarstwa rolne, grupy producenckie i marketingowe, rynki hurtowe, wystawy, targi oraz Agencja Rynku Rolnego, a zniknęly inne (np. państwowe gospodarstwa rolne, centrale handlu zagranicznego) [Morkis, Chechelski 2000].

Zmniejszyła się liczba kanałów dystrybucji żywności, a także stale zmienia się ich udział w rynku. Zmniejszyły się udziały takich odbiorców, jak przedsiębiorstwa przemysłowe, handel detaliczny, giełdy towarowe, sklepy i hurtownie własne. Nastąpiło także ograniczenie udziału w rynku surowców indywidualnych rolników, zwłaszcza dysponujących małą wielkością produkcji. Dość powszechna była niska jakość surowców oferowanych przez tych uczestników rynku. Nastapiło odejście przedsiębiorstw przemysłu spożywczego od kontraktacji u tych producentów. Zwiększył się natomiast udział hurtowni hiperi supermarketów, sieci handlu detalicznego oraz grupy „innych odbiorców”. Zmieniła się również i rola kanałów dystrybucji, gdyż oprócz fizycznego przemieszczania wyrobów stały się one także dostarczycielami informacji o potrzebach rynkowych.

Procesy integracyjne mog̨ mieć charakter defensywny (obrona własnych interesów poszczególnych uczestników procesu wytwarzania żywności i obrotu nia) lub ofensywny (dążenie do rozwoju i umocnienia pozycji uczestników przez pionowe grupowanie ich działalności) [Laskowska, Pieniążek, Zdyb 1987].

Największe możliwości rozwoju obydwu form integracji istnieją w agrobiznesie. Agrobiznes jest częścia gospodarki narodowej i obejmuje wszystkie ogniwa potrzebne do wytwarzania żywności, a następnie dostarczenia jej konsumentowi. Szczególnie duże możliwości rozwoju procesów integracyjnych w agrobiznesie wynikaja $\mathrm{z}$ faktu, że między wytworzeniem surowca żywnościowego a dostarczeniem żywności konsumentowi jest wiele faz produkcji i dystrybucji, gdzie dzięki integracji pionowej można racjonalizować koszty. Wynika to także z rozdrobnienia struktury obszarowej - make gospodarstwa rolne mogą oferować nieduże partie surowców żywnościowych, dzięki zaś integracji poziomej mogą uzyskać podobną siłę przetargową jak sieć sklepów detalicznych [Małysz 1996]. 


\section{Integracja pionowa}

Integracja pionowa to łączenie się podmiotów gospodarczych z różnych faz procesu produkcji i.dystrybucji [Małysz 1996]. W tym przypadku łączeniu podlegają podmioty gospodarcze związane z produkcją żywności, lecz o różnym profilu i zakresie działalności.

Ponadto, można wyróżnić integrację skierowaną w przód oraz wstecz. Integracja oddolna (skierowana w przód) polega na przejmowaniu roli integrujacego przez związki poziome rolników, najczęściej ich spółdzielnie lub spółki kapitałowe. Forma ta umacnia pozycję rolników w układzie zintegrowanym. Integracja odgórna (skierowana wstecz) polega na przejmowaniu roli przez jednostkę pozarolnicza: zakład przemysłu spożywczego lub firmę handlowa. $\mathrm{W}$ tej formie ochronę interesów rolników może zapewniać państwo [Strużek 1996].

Do roli integratora predysponowane sa, według Barkera [1989], firmy przemysłu spożywczego. Usytuowane są bowiem niejako pośrodku między producentami surowców a finalnymi konsumentami żywności. Mogą prowadzić marketing, wyznaczać parametry jakościowe surowców i technologie ich wytwarzania oraz korzystne dla obu stron warunki transakcji handlowych.

Od strony rolnictwa dobrowolne wchodzenie w związki integracyjne może być konsekwencją świadomego wyboru rolników. W gospodarce rynkowej funkcjonują bowiem równolegle różne systemy zbytu płodów rolnych i zaopatrzenia rolnictwa w środki produkcji. Sprzedając produkty rolne, ich wytwórcy mogą korzystać z pośrednictwa agentów, dealerów, hurtowników, jak też zbywać produkty na giełdach i aukcjach.

Rolnik, który stara się racjonalnie gospodarować, musi większość czasu i energii poświęcać na produkcję i przygotowanie produktów do zbytu, Nie jest w stanie systematycznie śledzić wahań cen, podaży, popytu, zmienności koniunktury, tak aby ulokować produkty w najbardziej dogodnym miejscu zbytu i po najwyższej cenie. Problem marketingu rolniczego rozwiązuje integracja pionowa, aby bowiem była ona efektywna, wymaga badania rynku, stosowania marketingu i wykorzystywania koniunktury [Barker 1989].

Integracja pionowa umożliwia stosunkowo łatwiejszą regulację równowagi rynkowej (popyt-podaż) oraz przyczynia się do ukształtowania stabilnej, wyspecjalizowanej bazy surowcowej. Rolnicy dzięki umocnieniu więzi z odbiorcą redukują ryzyko produkcji, zapewniając sobie gwarancję odbioru, a niekiedy mogą nawet podwyższyć cenę zbytu swoich produktów. Efektem integracji jest obniżenie kosztów własnych produkcji [Laskowska, Pieniążek, Zdyb 1987]. 
Integracja pionowa rolnictwa i przemysłu spożywczego jest procesem wywołanym przez pogłębiający się podział pracy, specjalizację oraz postęp (biologiczny, techniczno-technologiczny, organizacyjny). Motorem procesu integracji są również zmiany w charakterze popytu na żywność [Laskowska, Pieniążek, Zdyb 1987]. Wszystkie te czynniki prowadzą do wykształcenia się wzajemnych zależności między podstawowymi elementami systemu wytwarzania żywności, tj. produkcją surowców, przetwórstwem oraz obsługą przedi poprodukcyjna.

Pionowe więzi integracyjne między podmiotami gospodarczymi powstają w wyniku:

- zawarcia kontraktu (integracja kontraktowa), tj. podpisania umów $\mathrm{z}$ dostawcami surowców, którzy produkująje na zamówienie odbiorcy,

- nabycia tytułu własności (integracja kapitalowa) i uruchomienia produkcji surowców żywnościowych na ziemi należącej do właściciela przetwórni,

- stanowienia norm prawnych przez państwo (integracja instytucjonalna), gdy państwo ustala sposób łączenia $z$ punktu widzenia przyjętych priorytetów.

\section{Kontraktowa integracja pionowa}

Pozycja producentów, którzy sprzedają tradycyjnymi kanałami, jest słaba. Jedną z szans na jej zwiększenie będzie zawarcie kontraktu z kupującym produkty. Kontrakty stosuje się w różnym zakresie. Dla pewnych kierunków produkcji są one bardzo ważne, podczas gdy w innych dziedzinach są mało użyteczne. Dawniej większość transakcji rynkowych pieczętowano uściskiem dłoni lub kończono opadnięciem młotka aukcyjnego. $Z$ biegiem czasu zaczęła się rozwijać sformalizowana praktyka zawierania kontraktów. Współczesna kontraktacja nie stanowi nowego jakościowo zjawiska, jednak w umowach kontraktacyjnych zaszły $w$ ciagu ostatnich lat radykalne zmiany, polegające na wprowadzeniu elementów produkcyjnych w celu zastosowania postępu technicznego $\mathrm{i}$ organizacyjnego kontraktowej produkcji.

Jak podaje Sznajder [1997], kontrakt jest to zobowiązanie dostarczenia określonego towaru w czasie i w ilości wymaganej przez kupca. Konieczne jest, aby w kontrakcie były określone zasady ustalania ceny kupna i sprzedaży. Kontraktacja ma korzystny wpływ na gospodarowanie. 
Kodeks cywilny ${ }^{3}$ określa, że w kontrakcie w formie pisemnej „producent rolny zobowiązuje się wytworzyć i dostarczyć kontraktującemu oznaczona ilość produktów określonego rodzaju, a kontraktujący zobowiązuje się te produkty odebrać $\mathrm{w}$ terminie umówionym, zapłacić umówioną cenę oraz spełnić określone świadczenie dodatkowe, jeśli umowa lub przepisy szczególne przewidują obowiązek takiego świadczenia". Świadczeniami mogą być premie pieniężne oraz rzeczowe, pomoc agrotechniczna i zootechniczna, zapewnienia nabycia środków produkcji. Kodeks określa także zakres odpowiedzialności, jeśli strony nie wywiązują się z umowy.

W rolnictwie stosuje się trzy typy kontraktów [Sznajder, Trębacz, Adamczyk 1997]:

- kontrakty sprzedaży, obejmujące sprzedaż produktu, który albo został wyprodukowany, albo jest w procesie produkcji; warunki zazwyczaj dotycza ceny, jakości i ilości produktu oraz terminu dostawy; kupujący nie ma wpływu na technike produkcji; kontrakty tego typu są dość powszechne dla produktów roślinnych,

- kontrakty zakupu, obejmujące nabywanie środków produkcji,

- kontrakty transferu zarzązania, przekazujące część lub całość odpowiedzialności właściciela $\mathrm{w}$ zakresie zarządzania; stopień przekazania odpowiedzialności zarządzania zależy od typu produkcji, np. w produkcji materiału siewnego zarządzanie może dotyczyć materiału siewnego, rodzaju oprysków oraz terminu ich stosowania.

Koordynujący wpływ kontraktów (umów) może redukować ryzyko produkcji surowca żywnościowego, zwiększać efektywność tej produkcji oraz ułatwiać dostęp do środków finansowych i inwestycyjnych. Kontrakt reguluje podaż surowca żywnościowego pod względem: ilości, jakości, terminu dostawy i cech zdrowotnych [Urban 2000].

Kontrakty stają się coraz ważniejsze w rolnictwie. Wiążą się z nimi zarówno wady, jak i zalety, co przedstawiono w tabeli 1 .

Stroną umów kontraktacyjnych mogą być nie tylko pojedyncze gospodarstwa, lecz także grupy producentów. Dotyczy to szczególnie dostaw takich produktów, które przed wysyłką do odbiorcy muszą być pỏddane procesowi wstępnej obróbki, np. czyszczenia, sortowania, pakowania czy też składowania.

Kontraktacja stanowi najlepszą formę zespolenia działalności handlowej z produkcyjna, dotyczy ona bowiem nie tylko stosunków wymiany, ale również bezpośrednio sfery produkcji. W jej systemie nakładają się na siebie stosunki handlowe, kredytowe, elementy bezpośredniej kooperacji produkcyjnej, wdrażanie postępu zootechnicznego, fachowe poradnictwo itp. [Zalewski 1989].

${ }^{3}$ Kodeks cywilny. Ustawa z 23 kwietnia 1964 r. Warszawa-Poznań 1991, s. 102. 
Tabela 1

Zalety i wady kontraktów

\begin{tabular}{|c|c|}
\hline Zalety kontraktów & Wady kontraktów \\
\hline $\begin{array}{l}\text { - producent ma zapewniony rynek dla } \\
\text { swojej produkcji z odpowiednio zagwa- } \\
\text { rantowaną cena, } \\
\text { - zagwarantowane ceny umożliwiają } \\
\text { bardziej zaawansowaną procedurę } \\
\text { w planowaniu zarządzania gospodar- } \\
\text { stwem, } \\
\text { - przy uzyskaniu określonej jakości na } \\
\text { pewno uzyskuje się wyższą cenę, } \\
\text { - możliwe są także dodatki za inne usłu- } \\
\text { gi, na przykład za terminowe dostar- } \\
\text { czenie produktu, } \\
\text { - producent jest stale informowany } \\
\text { o wszystkich możliwych postępach } \\
\text { w zakresie techniki produkcji, } \\
\text { - dla niektórych produktów kontrakty sa } \\
\text { właściwie jednym sposobem sprzedaży } \\
\text { produkcji; przykładem są buraki cukro- } \\
\text { we czy chmiel. }\end{array}$ & $\begin{array}{l}\text { - producent ma mniejsze możliwości } \\
\text { skorzystania z niespodziewanych zy- } \\
\text { sków, które mogą pojawić się w wypad- } \\
\text { ku zwiększenia się cen na rynku, } \\
\text { - kupujący może nalegać na stosowanie } \\
\text { specjalnych metod produkcji oraz pew- } \\
\text { nych wybranych środków produkcji; } \\
\text { może to zwiększyć koszty produkcji bez } \\
\text { kompensacji przychodów, } \\
\text { - kupujący ponosi większość ryzyka } \\
\text { i dlatego dąży do zrównoważenia go } \\
\text { przez zachęcanie rolnika do ciaglych } \\
\text { udoskonaleń i efektywności gospoda- } \\
\text { rowania, } \\
\text { - można wprowadzić kary za zła jakość, } \\
\text { - kontrakty nikomu nie dają całkowitego } \\
\text { bezpieczeństwa. }\end{array}$ \\
\hline
\end{tabular}

Źródło: M. Sznajder, A. Trębacz, G. Adamczyk: Rynek rolny. Poznań 1997, s. 57.

Kontraktacja w zależności od formy i zasięgu może mieć większy lub mniejszy stymulujący wpływ na wykształcenie się więzi pionowych. Najmniejszy wpływ mają kontrakty luźne o charakterze umów handlowych, obejmujące tylko ustalenia co do ilości, cen i czasu dostawy towarów. Podobne znaczenie mają kontrakty zakupowe, obejmujące - oprócz tego - dostawy środków produkcji. Większą rolę odgrywają kontrakty produkcyjne obejmujące - obok wymienionych elementów - kontrolę produkcji rolnej [Piwowar 1998].

Rozwój integracji pionowej może być jednym z czynników zmieniających strukturę polskiego rolnictwa oraz poprawiających jego efektywność, gdyż rozszerzenie i pogłębienie kontraktacji będzie prowadzić do [Piwowar 1998]:

- wyselekcjonowania grup towarowych i nowoczesnych gospodarstw rolnych o skali produkcji i efektywności gospodarowania konkurencyjnych $\mathrm{z}$ rolnictwem Unii Europejskiej oraz stwarzających im trwałe podstawy rozwoju,

- rozwoju specjalizacji produkcji w rolnictwie, a przez to do poprawy jego efektywności, gdyż nawet największe i najlepsze gospodarstwa będą musiały się specjalizować w jednym lub w 2-3 kierunkach produkcji rolnej, 
- dopływu do rolnictwa dodatkowego kapitału, organizowanego przez integratora, pozwalającego na modernizację gospodarstw rolnych.

Ponadto, lepsze dostosowanie podaży do wymagań odbiorców zapewni możliwość osiagnięcia przez rolników wyższych cen za sprzedane produkty, a więc będzie jednym $z$ czynników poprawy sytuacji dochodowej rolnictwa i zwiększenia zdolności samofinansowania modernizacji tego działu.

\section{Integracja kapitałowa}

Wspótpraca rolnictwa, przetwórstwa i. handlu żywnością odbywa się w ramach różnych form powiązań pionowych. Integratorzy zaopatrują się w produkty rolnicze na podstawie kontraktacji lub umów handlowych, tj. więzi o mniejszym stopniu zaangażowania integratora w produkcję rolnicza. Umowy te stwarzają partnerom swobodę wyboru, jednak pozwalają na określenie wymagań dotyczących jakości, terminów dostaw i innych warunków.

Występują trzy rodzaje związków umownych [Laskowska, Pieniążek, Zdyb 1987]:

a) umowy rynkowe $\mathrm{z}$ oznaczeniem warunków zakupu towarów,

b) umowy (partial management transfer), na mocy których kupujący dostarcza tyko niektóre środki produkcji i ma udział w podejmowaniu decyzji produkcyjnych, przy czym nie jest on właścicielem produktów zanim opuszczą one gospodarstwo,

c) umowy nakladcze (full management), na mocy których nabywca dostarcza większość środków produkcji, specyfikuje, w jaki sposób powinien przebiegać proces produkcji oraz na ogół jest właścicielem dostarczonych gospodarstwu towarów i produktu finalnego.

Wśród czynników integrujących rolnictwo z przemysłem można wyróżnić: zaopatrzenie $w$ podstawowe środki produkcji, wspólne terytorium działania, transfer postępu, wspólny zbyt, a w ostatnich latach także solidarny podział ryzyka produkcji i zbytu [Laskowska, Pieniażek, Zdyb 1987].

Niektóre gospodarstwa, dogodnie położone względem odbiorcy, mogą podejmować produkcję nakładcza, oznacza ona jednak duże uzależnienie. W przypadku braku koniunktury na rynku produktów finalnych nakładca może usiłować przerzucić ryzyko zbytu na wytwórcę lub poszukiwać tańszego dostawcy. Ochrona prawna pod tym względem w praktyce jest mało skuteczna.

Integracja mająca cechy systemu nakładczego ogranicza rolę producenta do świadczenia tylko pracy lub pomieszczenia na produkcję. Następuje tu łączenie kapitału przemysłowego $\mathrm{z}$ rolniczym przez nabycie tytułu własności (integracja instytucjonalna) i uruchomienie produkcji surowców żywnościo- 
wych na ziemi należącej do właściciela przetwórni (na przykład, rzeźnia kupuje ziemię rolniczą i prowadzi na niej chów zwierząt rzeźnych na własne potrzeby). Integrator pozarolniczy przejmując kapitały $\mathrm{z}$ rolnictwa zleca producentowi surowców rolnych wykonywanie pracy, której rezultaty kupuje. W tym przypadku zachodzi pełna kontrola procesu produkcji rolniczej, rolnik jest wynagradzany za swoją pracę, udostępnienie ziemi lub budynków. Pełnienie funkcji zarządzających produkcją rolniczą jest wtedy całkowicie przeniesione na integratora. Rolnicy bronią się przed tą formą kontraktu, zawierając ją jedynie na część prowadzonej produkcji [Piwowar 1998].

\section{Integracja instytucjonalna}

Integracja między rolnictwem i przemysłem spożywczym w systemie rynkowym zachodzi w określonym otoczeniu, na które składają się głównie trzy sfery:

- gra rynkowa $i$ jej uczestnicy (podmioty gospodarcze, gospodarstwa domowe);

- regulacje niecenowe (cła, podatki, kredyty, kursy dewizowe);

- otoczenie spoleczne i środowiskowe (w tym wieś i środowisko naturalne);

- infrastruktura instytucjonalno-rynkowa;

- interwencjonizm państwowy (państwo, samorządy, banki, giełdy, fundacje, agencje rządowe, związki zawodowe).

Gra nynkowa jest podstawą wymiany towarowo-pieniężnej, umożliwiając duże korzyści finansowe silnym i sprawnym jej uczestnikom. Więzi pionowe kształtują się w ramach funkcjonowania mechanizmu rynkowego, ale są nawiq̨zywane w celu obrony przed niedoskonałościami i żywiołowością rynku. Sa udaną próbą stabilnego i w miarę trwałego funkcjonowania podmiotów osiągających sukces na rynku, czego dowodzi praktyka krajów rozwiniętych gospodarczo [Piwowar 1998].

Stanowienie norm prawnych przez państwo może stymulować integrację. Występuje to wtedy, gdy państwo ustala sposób łączenia z punktu przyjętych priorytetów (np. wspiera dotacjami zespoły producenckie, jak to się dzieje w RFN). Doświadczenia krajów Unii Europejskiej pokazują że państwo może wspierać integracje w różny sposób: przez uregulowania legislacyjne lub fiskalne (przywileje podatkowe). Warunkiem koniecznym jest otwarcie na rynki zagraniczne (realizowane przez politykę celna) oraz uzasadnione subsydiowanie produktów o znaczeniu strategicznym. Według Hunka [2000], polityka rolna powinna obejmować również pozarynkowe formy interwencjonizmu, tj. działania kontrolno-stymulujące oraz stabilizująco-osłonowe. Szczególna rola 
przypada państwu w zakresie sterowania jakością produktów rolniczych, zwłaszcza gdy w perspektywie może nastąpić ujednolicenie wymagań jakościowych (przynajmniej w Europie).

Otoczenie wpływa w różnorodny sposób na procesy integracyjne: reguluje je, weryfikuje efektywność, stymuluje lub hamuje te procesy. Wpływ układu zintegrowanego na otoczenie jest niewielki, jednakże w przypadku dominacji na rynku może on w znacznej mierze kształtować podaż $\mathrm{i}$ ceny na wybranych rynkach cząstkowych [Hunek 2000].

Infrastruktura rynku jest materialno-techniczną bazą rozwoju więzi pionowych. $Z$ reguły im wyższy poziom rozwoju sieci handlu hurtowego i detalicznego, doskonalszy obieg informacji rynkowej, lepsza łączność i nowocześniejsze nośniki komunikacji (sieci komputerowe), tym lepsze warunki do rozwoju powiązań pionowych [Hunek 2000]. Niezmiernie ważne są instytucje rynkowe, zwłaszcza banki i giełdy. Banki mogą być uczestnikami porozumień integracyjnych niezależnie od tego, że prowadzą obsługe finansowo-rozliczeniową i kredytową. Banki mogą uczestniczyć w wielostronnych porozumieniach integracyjnych, obejmujących rolników, zakłady przemysłu spożywczego, firmy handlowe i gastronomiczne. Szczególną jednak rolę w stymulacji procesów integracyjnych odgrywaja giełdy towarowe. Sq one miejscem, gdzie podmioty rynkowe nawiązują kontakty handlowe, będące początkiem trwalszych powiązań. Istotna jest powtarzalność transakcji na giełdzie i stałość reguł jej funkcjonowania. Giełda, jako wysoce unormowana forma organizacji rynku, polega na regularnych, umiejscowionych w oznaczonym czasie i miejscu spotkaniach sprzedajacych i kupujących towary. Dla rozwoju integracji pionowej istotne są szczególnie informacyjne funkcje giełdy oraz wymogi dotyczące przestrzegania norm jakościowych; mniej ważne wydają się inne funkcje, jak zagospodarowanie podaży i usprawnienie obrotu [Sznajder, Trębacz, Adamczyk 1997].

Znaczne zróżnicowanie warunków produkcji, brak infrastruktury technicznej handlu oraz nawyki i postawy rynkowe - zarówno w rolnictwie, jak i w jego otoczeniu - sprawiaja, że niezbędna okazuje się polityka interwencyjna państwa. Regionalne zróżnicowanie cen w gospodarce żywnościowej i wycofywanie się z produkcji towarowej grup producentów rolnych niezdolnych do konkurencji cenowej i jakościowej powoduje, że rola aktywnego uczestnika rynku przypada państwu, za pośrednictwem różnego rodzaju agend rządowych [Wiatrak 2000].

Zakładanym celem interwencji rzadu na rynku rolnym jest poprawienie jego efektywności. W procesie wymiany produktów rolniczych uczestniczą różne jednostki związane bezpośrednio lub pośrednio $\mathrm{z}$ obrotem towarowym: należą do nich [Janiszewski 1998]: 
a) agencje rządowe (Agencja Rynku Rolnego, Agencja Nieruchomości Rolnych, Agencja Restrukturyzacji i Modernizacji Rolnictwa),

b) agencje prowadzące badania rynkowe,

c) agencje reklamowe,

d) banki,

e) spółdzielnie handlowe,

f) giełdy, aukcje,

g) rynki hurtowe,

h) targowiska,

i) inne jednostki wspomagające działania rynkowe.

Wymienione jednostki biorą bezpośrednio udział $\mathrm{w}$ wymianie towarowej lub wydatnie ją wspierają przez różne działania dostarczające, interwencyjne, promocyjne, a także udzielanie niezbędnej informacji i wspieranie finansowe.

W Polsce państwową jednostką organizacyjna, realizującą interwencyjną politykę, jest Agencja Rynku Rolnego (ARR) utworzona w połowie $1990 \mathrm{r}$. Agencja działa poprzez mechanizm rynkowy, a nie w sposób administracyjny. Realizacja interwencyjnej polityki rolnej przez ARR ma na celu:

a) stabilizację rynku rolno-żywnościowego,

b) ochronę dochodów uzyskiwanych $\mathrm{z}$ rolnictwa.

\section{Integracja pozioma}

Odrębnym problemem jest nieuchronność rozwoju integracji poziomej ${ }^{4}$ w kolejnych ogniwach łańcucha żywnościowego. Przykładem więzi poziomych w przemyśle spożywczym są fuzje zakładów przetwórczych, wynikające z zacieśniającej się współpracy lub z przejmowania przedsiębiorstw słabych i bankrutujących przez firmy wiodące na rynku.

Zamiast łączyć podmioty gospodarcze (fuzja), można integrować poziomo wyodrębnione czynności w celu lepszego ich wykorzystania lub zmniejszenia kosztów wytwarzania (np. wspólne zaopatrzenie w surowiec, wspólna sprzedaż produktów lub ich promocja). Mamy wówczas w dalszym ciagu do czynienia z samodzielnymi podmiotami gospodarczymi, które jednak podjęły decyzje o określonym wspólnym działaniu [Małysz 2000].

Integrując poziomo wybrany rodzaj działalności gospodarczej (np. dystrybucję), firmy odnoszą korzyści dzięki oszczędności kosztów handlowych, rezygnacji $\mathrm{z}$ walki konkurencyjnej i zwiększonej sile przetargowej na rynku.

\footnotetext{
${ }^{4}$ Integracja pozioma, to łączenie się ze sobą podmiotów gospodarczych należących do tej samej fazy produkcji lub dystrybucji.
} 
Broniąc swych interesów ekonomicznych, rolnicy poprawiają swoją pozycję na rynku organizując spółdzielnie, grupy marketingowe, zespoły producenckie albo tylko grupową sprzedaż produktów.

W nowoczesnej gospodarce znaczącą rolę będzie spełniać integracja pozioma o charakterze instytucjonalnym ${ }^{5}$, organizowana przez związki producentów jednego produktu lub grupy wyrobów. Zalążki takich związków powstały w latach dziewięćdziesiątych, ale siła ich oddziaływania jest niewielka. Takie poziome związki mogą pełnić następujące funkcje [Urban 2000]:

- uzgadniać stanowisko dużej grupy podmiotów w negocjacjach $\mathrm{z}$ innymi partnerami w sprawie ramowych warunków dostaw surowca lub wyrobów gotowych i reprezentować je wobec podobnych organizacji i partnerów rynkowych,

- reprezentować interesy swoich członków wobec władz państwowych, samorządowych czy też związków zawodowych,

- inicjować regulacje prawne i rozwiązania instytucjonalne odpowiadające danej grupie interesów,

- reprezentować interesy polskich producentów lub handlowców po integracji z Unią w realizacji wspólnej polityki rolnej, żywnościowej czy też handlowej,

- organizować przepływ informacji ważnych dla działalności gospodarczej prowadzonej przez członków związku,

- organizować doradztwo techniczne, ekonomiczne i inne, szczególnie dla małych i średnich firm w dziedzinach, w których nie będą one zdolne samodzielnie rozwiązywać swoich problemów,

- badać rynek zbytu, promować wyroby członków oraz informować ich o potencjalnych odbiorcach.

Najbliższe lata wymagają szybkiego rozwoju poziomych struktur i organizacji producentów - zarówno rolników, jak i przetwórców. W strukturach tych szczególną rolę reprezentanta interesów całego przemysłu spożywczego może spełnić Polska Federacja Producentów Żywności.

\footnotetext{
${ }^{5}$ Zmiany instytucjonalne rozumiane w szerokim ujęciu proponowanym przez kierunek ekonomiczny zwany instytucjonalizmem. Przedstawiciele tego kierunku wyróżniają trzy płaszczyzny rozpatrywania zmian instytucjonalnych:

- porządek prawny (ład prawny), zwany instytucjami ogólnymi,

- instytucje konkretne, do których zaliczają przedsiębiorstwa, aparat gospodarczy państwa, związki pracodawców, związki zawodowe itp.,

- mechanizmy makroregulacji.
} 


\section{Zespół producencki}

Zespół producencki jest tworzony w trybie dobrowolnym. Rolnicy łączą się w celu zespołowego zbywania swej produkcji. Grupy producenckie tworzone są przez wytwórców tych samych produktów bądź grup produktów (np. ziemniaków, zbóż, warzyw). Powstanie grup producenckich i grup marketingowych jest jedną $z$ form przedsiębiorczości w środowisku wiejskim. SMają one zapewnić grupie pojedynczych producentów rolnych zbyt wytwarzanych przez nich produktów rolnych i silne, stałe powiązanie z rynkiem żywności.

Wspólne działanie rolników ma w pierwszej fazie ograniczyć się co najmniej do wspólnego zbytu, który nie wymaga dużego kapitału założycielskiego i początkowo można obejść się bez dużych.inwestycji. W miare gromadzenia zysków powstaje możliwość inwestowania w urządzenia do wstępnego przetwarzania, przechowywania i transportu [Małysz 1996].

Pojedynczy rolnik, zwłaszcza gdy wytwarza nieduże ilości produktu, często nie ma innej możliwości jego zbytu niż na podstawie kontraktu zawieranego $z$ najbliższą firmą-integratorem. Grupa producencka może już wybierać między ofertami kilku firm-integratorów, a ponadto $\mathrm{z}$ pozycji dużego dostawcy osiagać korzystniejsze warunki kontraktu. Wykorzystując swoją pozycję przetargowa. zespół może uzyskać korzystniejsze ceny, dłuższe kontrakty, dodatkowe usługi produkcyjne. W zamian może zaoferować dostawę większych partii surowca dobrej jakości [Hunek 2000].

Zawsze jednak firma-integrator stanowi dla grupy producenckiej forme rynku, zwanego ,rynkiem pierwotnym" (por. rys. 1). Firma-integrator dostarcza bowiem informacji o cenach, o jakości, o prezentacjach konsumentów oraz przekazuje informacje o najnowszej technologii $i$ technice. Istnienie rynku pierwotnego zwalnia grupe producencką od samodzielnego badania rynku [Małysz 1996].

Producenci rolni zorganizowani w grupy mogą osiągać wyższy poziom koncentracji, zwiększyć poziom jakości i jednorodności produktów, zapewnić ciagłość dostaw, lepsze metody sortowania produktów oraz dostaw. Przedsiębiorstwom przemysłu spożywczego powinno to zapewnić surowiec lepszy jakościowo, dostarczany w większych partiach i w bardziej optymalniejszych terminach [Chechelski, Morkis 1999]. Dlatego też zachęta do tworzenia grup powinna pochodzić od przedsiębiorstw hurtowych i detalicznych zainteresowanych regularnymi dostawami.

Nowo powstające grupy producenckie przyjmują różne formy organizacyjno-prawne, takie jak spółdzielnie, zrzeszenia, stowarzyszenia lub 'spółki. W warunkach polskiego rolnictwa grupowe przedsięwzięcia producentów rolnych są niewattpliwie konieczne. Rolnicy indywidualni nie są jednak przekonani do tej formy działalności, co wynika z przekonań ukształtowanych w okresie socjalizmu. 


\section{FIRMA PRZEMYSEU SPOŻYWCZEGO}

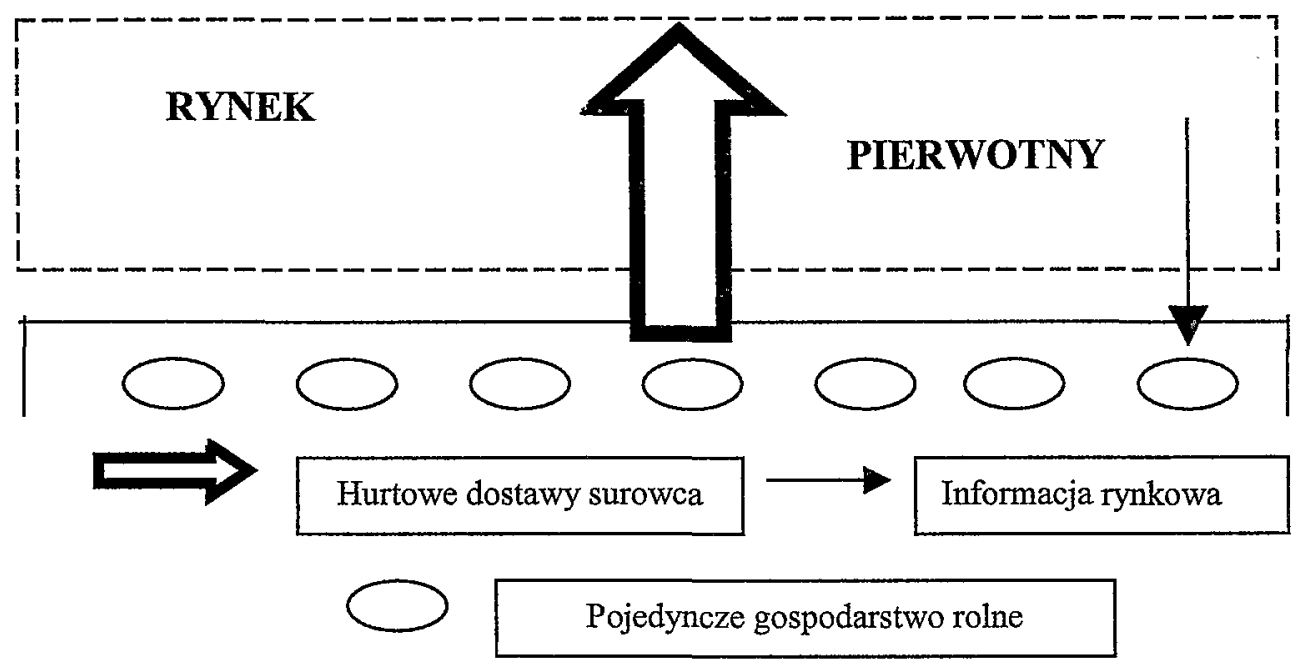

\section{Rysunek 1}

Powiązania między zakładem przetwórczym a grupą producencką Źródło: J. Małysz, 1996: Procesy integracyjne w agrobiznesie... op. cit., s. 15.

Integracja pozioma (zespół producencki, spółdzielnia, spółka kapitałowa rolników) może co prawda radykalnie poprawić pozycję przetargową rolników wobec firmy przetwarzającej, ale niepowodzenie integracji poziomej stanowi większe zło niż brak integracji poziomej. W razie niepowodzenia rolnicy popadają W zwiększoną zależność od integratora [Siekierski 1998].

\section{Zespół marketingowy}

Nową formą działalności dla spółdzielni, obok grup producenckich, mogą być zespoły (grupy) marketingowe, które działają już w takich krajach, jak Wielka Brytania, Włochy i Stany Zjednoczone. Za tą formą działalności przemawia podstawowe źródło siły grupy producentów, którym - podobnie jak w spółdzielczości - jest jedność członków.

Zespół marketingowy powstaje wówczas (rys. 2), gdy producenci porozumiewają się co do warunków wspólnej sprzedaży swoich produktów, przygotowania ich $\mathrm{w}$ partie jednolite pod względem jakościowym oraz sposobu pro- 
wadzenia ich dystrybucji, promocji i wysokości cen. Drugą formą zespołu marketingowego jest grupa producencka, która wykracza swoją działalnością poza rynek pierwotny. $Z$ reguły przeobrażenie się grupy producenckiej $w$ zespół marketingowy odbywa się ewolucyjnie. Początkiem staje się podział jednego kanału sprzedaży (zbyt tylko do firmy przetwarzającej surowiec) na kilka kanałów: grupa producencka może dostarczać swe produkty na lokalny rynek hurtowy, na rynek hurtowy ponadregionalny i wreszcie na giełdę [Małysz 1996].

Reasumując, grupę marketingową można określić jako związek producentów wspólnie sprzedających produkty, zaopatrujących się w środki do produkcji, stosujących jednolite technologie wytwarzania, produkujących wyroby o określonej jakości i określonym standardzie. Podstawową korzyścią ekonomiczną wynikająca ze wspólnego działania rolników w zespole marketingowym jest przejęcie zysku realizowanego dotychczas przez firmy handlowe i przemystowe działające w agrobiznesie.

Najważniejsza zmiana, która dokonuje się w wyniku opisanej ewolucji, to konieczność zastapienia zarządzania zbytem przez zarządzanie marketingowe. Bezpośredni kontakt $z$ rynkiem oznacza, że współdziałanie ograniczające się do zapewnienia jak najkorzystniejszego zbytu przekształca się we współdziałanie mające za cel jak najlepsze dostosowanie podaży do popytu konsumentów.

Inna zmiana polega na tym, że skala współdziałania staje się na tyle duża, że stwarza możliwości uruchomienia własnych firm przetwórczych i własnych sklepów detalicznych, zaopatrywanych własnym transportem. Zespół marketingowy staje się integratorem pionowym $i$ tworzy oddolny łańcuch integracyjny, sięgający aż po sprzedaż detaliczną żywności wytworzonej z własnego surowca.

Tego typu pionowy łańcuch integracyjny, tworzony z wykorzystaniem kapitału zespołu marketingowego, uważany jest za rozwiązanie korzystniejsze dla rolników od integracji pionowej, powstającej na podstawie kapitału napływającego do rolnictwa, gdzie integratorem jest firma nierolnicza [Chechelski, Morkis 2000].

Można wyróżnić wiele rodzajów grup produkcyjno-marketingowych ze względu na formę organizacyjna, rodzaj realizowanych funkcji i zakres produktowy. W przypadku tej formy organizacyjnej można mówić o spółdzielniach, stowarzyszeniach, spółkach cywilnych i kapitałowych.

Niewielki udział w obrocie towarami rolno-spożywczymi grup produkcyjno-marketingowych $w$ Polsce wynika $z$ wielu przyczyn. Do najważniejszych można zaliczyć [Siekierski 1998]: 


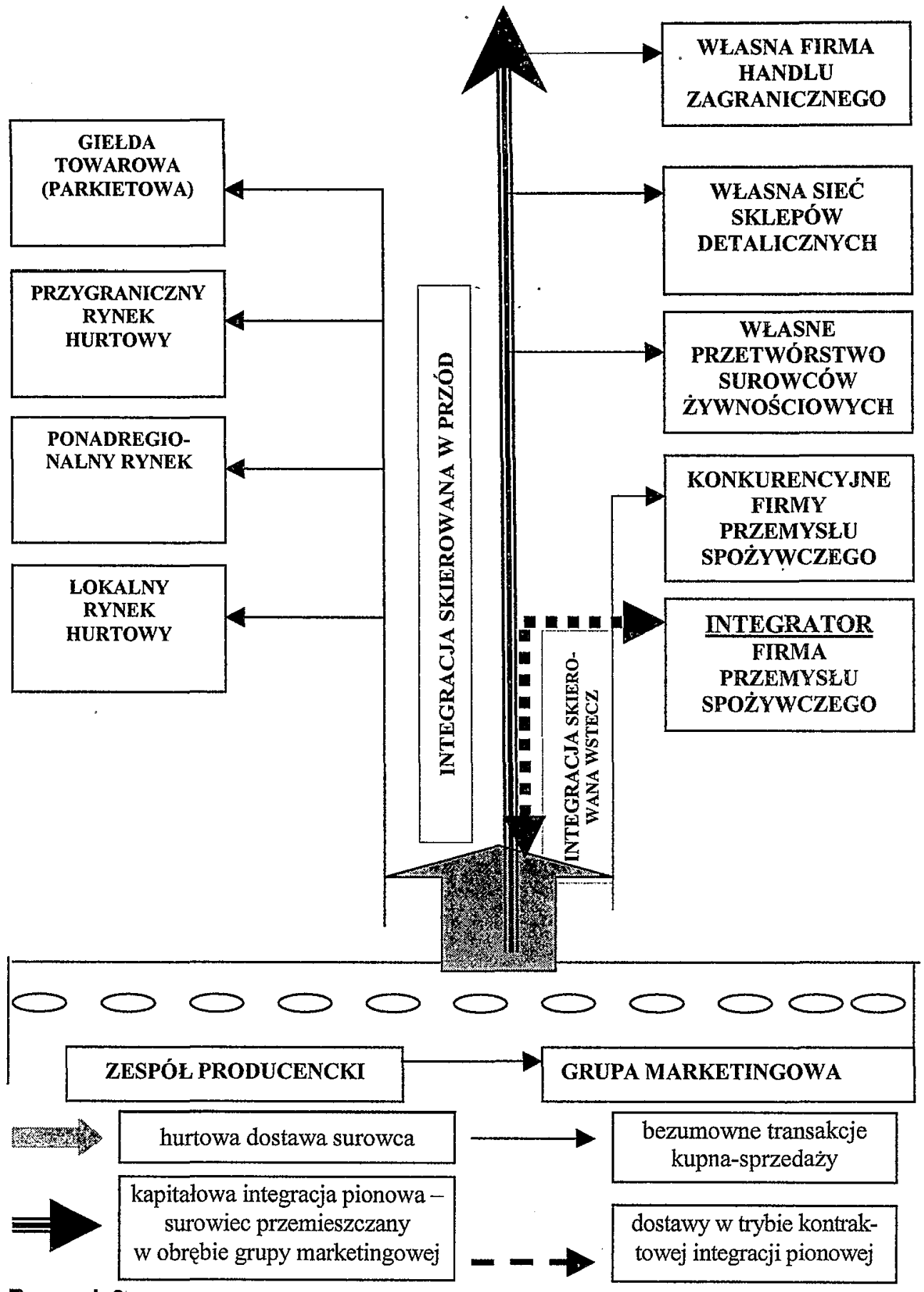

Rysunek 2

Rodzaje powiązań grup producenckich i marketingowych z rynkiem

Źródło: Tamże, s. 16. 
- zniszczenie idei spółdzielczości w PRL,

- niechęć producentów rolnych do wspólnych działań,

- niewielką zdolność polskich producentów rolnych do adaptowania swoich postaw i działalności gospodarstw do warunków gospodarki rynkowej,

- niski poziom świadomości ekonomicznej producentów rolnych,

- brak przepisów prawnych (zwłaszcza podatkowych), zachęcających do tworzenia grup produkcyjno-marketingowych,

- ograniczone możliwości finansowe państwa i konieczność finansowania innych programów rządowych (związanych $z$ rolnictwem $\mathrm{i}$ innymi działami gospodarki narodowej).

Rozwój grup produkcyjno-marketingowych w opinii Hunka [2000] powinien być pobudzany i sterowany programami instrumentalnymi ze strony: państwa, związków rolniczych, uczelni rolniczych, ośrodków doradztwa rolniczego i innych podmiotów na rynku rolnym (np. przedsiębiorstwa spożywcze). Należy stworzyć korzystne warunki podatkowe dla działania takich grup.

\section{Fuzje w agrobiznesie}

Fuzja $^{6}$ jest to proces łączenia dwóch lub większej liczby firm w jedną organizację gospodarcza; jest jednym ze sposobów podwyższania potencjału produkcyjnego przedsiębiorstw lub zwiększania ich pozycji na rynku. Fuzje są decyzjami inwestycyjnymi, należą więc do decyzji strategicznych.

Wyróżnia się trzy rodzaje fuzji [Grontkowska 2000]:

- pionowa,

- pozioma,

- konglomeratowa.

Fuzja pionowa to łączenie $w$ jedną organizację gospodarczą przedsiębiorstw składających się na cały ciąg wytwarzania i przetwarzania produktu (np. od produkcji żywca wieprzowego do przetworzenia go w produkt finalny).

Fuzja pozioma to łączenie się przedsiębiorstw tej samej branży dążących do dywersyfikacji działalności i oferowania na rynku bogatszego zestawu produktów. Fuzja pozioma ma na celu stworzenie silnej bazy surowcowej, powołanie wspólnego biura koordynacji sprzedaży oraz prowadzenie wspólnej polityki inwestycyjnej i marketingowej.

\footnotetext{
${ }^{6}$ Fuzja ma miejsce, gdy przedsiębiorstwa zgadzają się połączyć ze sobą (w spółkach akcyjnych nazywa się to unią) lub gdy jedna albo kilka firm wyraża zgodę na wykupienie przez przedsiębiorstwo - inicjatora fuzji (w spółkach akcyjnych taką operację nazywamy inkorporacja). Spólka uruchamiająca procesy łączenia wykupuje co najmniej kontrolne pakiety akcji w przyłączanych lub przejmowanych spółkach i w ten sposób centralizuje władzę w nowo tworzonej organizacji.
} 
Fuzja konglomeratowa polega na łączeniu przedsiębiorstw niezwiązanych rodzajem działalności. Celem ich łączenia jest zróżnicowanie portfela produkcji, szybki przyrost sprzedaży lub zamiar zyskownego wykorzystania nadwyżki środków finansowych. Przykładem konglomeratu w agrobiznesie może być lokowanie przez bank kapitału w ziemi rolniczej lub przedsiębiorstwie przemysłu spożywczego.

Fuzją organizacyjną powstająca w wyniku łączenia jest np. holding. Jest to spółka akcyjna posiadająca pakiet kontrolny akcji w przyłączonych spółkach i w ten sposób decydująca o całej organizacji. Fuzje, niezależnie od rodzaju, zwiększają siłę monopolistyczną powstałych jednostek.

\section{Uwagi końcowe}

1. Wprowadzenie zasad gospodarki rynkowej wywołało tendencje do uściślania powiązań ekonomicznych i organizacyjnych między dostawcami i odbiorcami. Niektóre funkcje sztucznie lokowane oraz przypisywane kontraktacji przejął rynek. Miejsce jednostki gospodarczej wobec innych uczestników rynku określa umiejętność dostosowania jej działalności do zmiennych relacji popytu i podaży. Coraz większego znaczenia nabiera czynnik czasu i jakości.

2. Powodem integracji rolnictwa, przetwórstwa i obrotu produktami rolniczymi jest konkurencja. Konkurencja na rynku żywności zmusza przedsiębiorstwa przemysłu spożywczego do walki o konsumenta. W rozgrywającej się na rynku żywności walce o klienta polskie przedsiębiorstwa przemysłu spożywczego muszą zagwarantować powtarzalną jakość wyrobów i poziom jakości, na jaki oczekuje coraz bardziej wymagający klient.

3. Wysoka jakość żywności, wymagana przez konsumentów, determinowana jest jakością i standaryzacją surowców rolnych i produktów spożywczych zastosowanych do jej produkcji. To z kolei zmusza przedsiębiorstwa przemysłu spożywczego do ściślejszej współpracy i powiązań z producentami rolnymi lub też do uruchamiania własnych jednostek, zajmujących się chowem lub uprawą.

4. Właściwe zarządzanie przepływami surowców i produktów oraz ich składowanie w sferze zaopatrzenia, produkcji i dystrybucji może przyczynić się do obniżenia kosztów działalności przedsiębiorstwa, a także podnieść jakość produkowanych wyrobów. W konsekwencji powinno to sprzyjać poprawie konkurencyjności przemysłu spożywczego oraz procesom integracji $\mathrm{z}$ jego otoczeniem rynkowym.

5. Procesy integracyjne wpływają bezpośrednio na kształtowanie się rynkowych warunków działania przedsiębiorstw i innych podmiotów gospodar- 
czych. W przypadku przemysłu spożywczego procesy integracyjne dotycza, $z$ jednej strony, podmiotów dostarczających surowce do przetwórstwa, a z drugiej-podmiotów odbierających wytworzone produkty.

6. Podstawowym celem integracji jest zwiększenie efektów gospodarowania, dodatkowym celem integracji jest eliminowanie ogniw pośrednich, czyli skrócenie drogi produktu od producenta do konsumenta.

\section{Literatura}

BARKER J.: Agricultural Marketing. Oxford University Press 1989.

Encyklopedia biznesu, Fundacja Innowacyjna, Warszawa 1995.

GRONTKOWSKA A.: Podstawy ekonomiki agrobiznesu. Część 2. WSiP, Warszawa 2000. HUNEK T. i in.: Dylematy polityki rolnej. FAPA, Warszawa 2000.

JANISZEWSKI J.: Polska polityka rolna w okresie negocjacji o członkostwo w Unii Europejskiej. W: Procesy dostosowawcze wybranych rynków rolnych w Polsce do regulacji w Unii Europejskiej. IERiGŻ, Warszawa 1998.

Kodeks cywilny. Ustawa z 23 kwietnia 1964 r. Warszawa-Poznań 1991.

LASKOWSKA I., PIENIĄŻEK K., ZDYB E.: Formy integracji przemyshu spożywczego i rolnictwa w niektórych krajch Europy. Ekspertyza. IERiGŻ, Warszawa 1987.

MALYSZ J.: W pojedynkę czy wspólnie z innymi rolnikami. Agrobazar nr 6/7, 2000.

MAEYSZ J.: Procesy integracyjne w agrobiznesie. CDiEwR, Poznań 1996.

MORKIS G., CHECHELSKI P.: Przewidywalne kierunki współpracy przemysłu spożywczego $\mathrm{z}$ otoczeniem rynkowym ze szczególnym uwzględnieniem przemysłu mleczarskiego. Przegląd Mleczarski nr 7, 2000.

MORKIS G., CHECHELSKI P.: Powiązania integracyjne przemysłu spożywczego $z$ otoczeniem rynkowym. IERiGŻ, Studia Monografie 90, Warszawa 1999.

PIWOWAR J.: System integracji rolnictwa z przemysłem spożywczym w Polsce. Politechnika Radomska, Radom 1998.

PIENIAZŻEK K.: Związki przemysłu spożywczego z rolnictwem - ewolucja i perspektywy. IERiGŻ, Warszawa 1991.

Rynek rolny (praca zb.). AR, Poznań 1997.

SIEKIERSKI C.: Grupy producenckie: cel czy sposób osiągnięcia celu?, Agrobazar 1998, nr $\dot{8}$.

STRUŻYK B.: Integracja pionowa i pozioma spółdzielczości jako warunek poprawy efektywności jej gospodarowania. W: Spółdzielczość wiejska w perspektywie integracji z Unią Europejska. SIB, Zakopane 1997.

URBAN R.: Polski przemysł spożywczy. IERiGŻ, Warszawa 2000.

WIATRAK A.: Założenia i cele polityki rolnej. W: Zagadnienia Doradztwa Rolniczego nr $2,2000$.

ZALEWSKI A.: Problemy gospodarki żywnościowej w Polsce. PWN, Warszawa 1989. 


\title{
The Types of Integration Connections in Agrobusiness
}

\begin{abstract}
Common actions play the rising role in today's world. The integration processes on an international scale influence on the integration processes between branches of agriculture and food processing industry on the country or region scale. There are distinguished two main types of integration: vertical and horizontal; sometimes it is said about diagonal (or cross) integration. It is also said about complete and indirect integration. The best possibilities of development both of the main integration forms exist in an agrobusiness. The agrobusiness is the part of the traditional economy and includes all of the elements necessary to the food producing and delivering to consumers.
\end{abstract}

